\title{
Akumulasi Fibrin dalam Anterior Chamber pada Kucing Penderita Tripanosomiasis dan Feline Immunodeficiency Virus
}

\section{Fibrin Accumulation in Anterior Chamber in Cat with Tripanosomiasis and Feline Immunodeficiency Virus}

\author{
Kurnia $^{1 *}$, Dyah Kunthi Wirapratiwi ${ }^{1}$, Setyo Budhi ${ }^{2}$, Guntari Titik Mulyani ${ }^{3}$, Dwi Priyowidodo ${ }^{4}$ \\ ${ }^{1}$ Rumah Sakit Hewan Prof. Soeparwi, Fakultas Kedokteran Hewan, Universitas Gadjah Mada \\ ${ }^{2}$ Departemen Bedah dan Radiologi, Fakultas Kedokteran Hewan, Universitas Gadjah Mada \\ ${ }^{3}$ Departemen Ilmu Penyakit Dalam, Fakultas Kedokteran Hewan, Universitas Gadjah Mada \\ ${ }^{4}$ Departemen Parasitologi, Fakultas Kedokteran Hewan, Universitas Gadjah Mada \\ *Email : kurnia.dvm@gmail.com
}

Naskah diterima : 3 Maret 2020, direvisi : 17 Juli 2020, disetujui : 1 Agustus 2020

\begin{abstract}
A male domestic cat three-years old admitted to Prof. Soeparwi veterinary hospital of Gadjah Mada University Yogyakarta with eye problem that both eyes appear whitish, starting from the left eye, a small size that develops progressively for 2 weeks, followed by a decrease in appetite and thin body condition. This unvaccinated cat originated from street cat, probably eating mice and birds. The white mass in both anterior chambers was the fibrin accumulation due to anterior uveitis in systemic infections of viral diagnoses (Feline Immunodeficiency Virus, Feline Infectious Peritonitis, Feline Leukemia Virus), toxoplasmosis, and systemic mycosis. Trypanosomiasis was also considered as a differential diagnosis, although rarely reported infect cats in Indonesia, trypanosomiasis also causes anterior uveitis. Physical examination was conducted and confirmed by laboratory tests consisting of hematology, SGPT, SGOT, albumin, total cholesterol, BUN, creatinine, blood smear, FIV/FeLV and toxoplasma rapid test. Clinical examination results showed anemic mucosa, dehydration, edema in the submandibular area to the shoulder, BCS 4/9, and anterior uveitis. Hematological and blood chemistry results showed normocytichypochromic anemia, thrombocytopenia, normal total leukocytes with relatively increased monocytes, very high SGPT and SGOT values, increased creatinine and decreased total cholesterol. The result of the rapid test showed positive FIV antibody, negative FeLV, and negative Toxoplasma. Blood smear examination showed a mild anemia without polychromasia and found Trypanosoma sp. A diagnosis of trypanosomiasis and FIV was confirmed. Fibrin accumulation in the progressive-bilateral anterior chamber accompanied by aqueous flare and normal retina which refer to anterior uveitis is a characteristic clinical symptoms of trypanosomiasis in cat and FIV infection.
\end{abstract}

Keywords: anterior uveitis; cat; Feline Immunodeficiency Virus; fibrin accumulation; Tripanosomiasis

\begin{abstract}
Abstrak
Seekor kucing domestik jantan berusia tiga tahun diperiksa di RSH Prof Soeparwi FKH-UGM Yogyakarta dengan keluhan kedua mata yang terlihat berwarna putih, berawal dari mata kiri, berukuran kecil yang berkembang secara progresif selama 2 minggu, diikuti penurunan nafsu makan serta kondisi badan yang semakin kurus. Kucing yang belum divaksinasi ini merupakan kucing jalanan yang gemar memakan tikus maupun burung. Masa putih yang melayang di kedua anterior chamber merupakan akumulasi fibrin akibat uveitis anterior pada infeksi sistemik dari diagnosa virus (Feline Immunodeficiency Virus, Feline Infectious Peritonitis, Feline Leukemia Virus), toxoplasmosis, dan systemic mycosis. Tripanosomiasis juga dipertimbangkan sebagai diagnosa banding, meskipun jarang dilaporkan menyerang kucing di Indonesia, tripanosomiasis juga menimbulkan lesi berupa uveitis anterior. Dilakukan pemeriksaan fisik yang diteguhkan dengan pemeriksaan laboratorium
\end{abstract}


berupa hematologi, SGPT, SGOT, albumin, total kolesterol, BUN, kreatinin, apus darah, rapid test FIV/FeLV dan rapid test toxoplasma. Hasil pemeriksaan fisik menunjukkan mukosa anemik, dehidrasi, oedema di daerah submandibular hingga bahu, BCS 4/9, dan uveitis anterior. Hasil pemeriksaan hematologi dan kimia darah menunjukkan anemia normositik-hipokromik, trombositopenia, normal leukosit total dengan peningkatan relatif pada monosit, nilai SGPT dan SGOT yang sangat tinggi, peningkatan creatinin dan penurunan total kolesterol. Hasil pemeriksaan rapid test menunjukkan positif antibodi FIV, negatif FeLV dan toksoplasma. Pemeriksaan apus darah menunjukkan anemia ringan tanpa polikromasia, dan ditemukan flagellata Trypanosoma sp. Kucing didiagnosa tripanosomiasis dan positif FIV. Akumulasi fibrin di dalam anterior chamber yang bersifat progresifbilateral disertai dengan aqueous flare dan normal retina merupakan gambaran anterior uveitis sebagai gejala klinis yang menciri dari Tripanosomiasis pada kucing dan infeksi FIV.

Kata kunci: akumulasi fibrin; Feline Immunodeficiency Virus; kucing; Tripanosomiasis; uveitis anterior

\section{Pendahuluan}

Tripanomiasis merupakan penyakit yang disebabkan oleh Trypanosoma sp, protozoa hemofagellata dari kelas Zoomatigophora dan famili Tripanosomatidae. Penyakit ini banyak dijumpai di daerah tropis, yaitu Afrika, Timur Tengah, India, Cina, Asia Tenggara dan Amerika Latin dengan berbagai spesies Tripanosoma yang berbeda, serta menyerang berbagai hewan domestik seperti kuda, sapi, kerbau, onta, anjing, kucing dan tikus. Di Indonesia, tripanosomiasis banyak dilaporkan menyerang kuda, sapi dan kerbau, menimbulkan kerugian besar yang luas pada aspek ekonomi dan sosial serta mendapat penanganan khusus dari pemerintah. Tripanosomiasis sangat jarang dilaporkan menyerang hewan peliharaan dan hewan liar di Indonesia, meskipun memungkinkan dapat terjadi pada hewan tersebut (Greene, 2012; Nurcahyo, 2017).

Penyebab jarangnya kasus tripanosomiasis pada kucing di Indonesia antara lain lingkungan kucing jauh dari lingkungan vektor spesifik Tripanosoma, tidak terdiagnosa, ataupun tidak terlaporkan. Menurut Bowman dkk. (2002) dan Nurcahyo (2017) vektor memegang peranan yang penting dalam penularan Trypanosoma sp. ke hospesnya seperti lalat Tabanus, Haematopota dan Chrysops sebagai vektor Tripanosoma evansi di Indonesia dan serangga Triatomid sebagai vektor Trypanosoma cruzi, Trypanosoma rangeli, dan Trypanosoma caninum di Amerika maupun Brazil. Vektor tersebut memiliki hospes spesifik dan beberapa hanya hidup pada wilayah greogafis tertentu. Beberapa penelitian mengenai tripanosomiasis pada kucing menurut Bowman dkk (2002), menggunakan probandus kucing yang diberi makan tikus ataupun daging kambing yang terinfeksi Tripanosoma sp. Hal ini memungkinkan kucing terinfeksi Trypanosoma melalui rute peroral, meskipun demikian tripanosomiasis pada tikus liar juga tidak banyak dilaporkan dan belum banyak diteliti. Gejala klinis yang spesifik dari tripanosomiasis mirip dengan gejala klinis penyakit lain yang lebihumummenginfeksikucing, sehingga tidak dipertimbangkan sebagai diagnosa. Menurut Silva dkk. (2009 $)$ terapi tripanosomiasis harus segera diberikan setelah kucing terdiagnosa untuk mencapai kesembuhan permanen dan mencegah kambuhnya tripanosomiasis.

Feline immunodeficiency virus (FIV) berasal dari family Retroviridae, subfamily Orthoretrovirinae, genus Lentivirus. Virus ini ditularkan melalui inokulasi air liur maupun darah dari pertarungan antar kucing. Feline immunodeficiency virus (FIV) mengganggu sistem kekebalan tubuh kucing menyebabkan disfungsi imun akibat adanya perubahan sitokin, hiperaktivasi Band T-limfosit non-spesifik, anergi imun dan apoptosis sel-T. Infeksi FIV berkembang dalam tiga tahap yaitu tahap primer sementara, tahap kronis yang asimtomatis, dan tahap kedua (terminal). Perjalanan infeksi FIV pada tahap primer berlangsung antara 6-8 minggu, virus bereplikasi secara cepat dan terdeksi adanya viremia melalui pemeriksaan PCR. Tahap kronis yang asimtomatis berlangsung selama bertahuntahun bahkan seumur hidup kucing, ditandai dengan rendahnya viremia dan adanya antibodi anti-FIV, namun disfusi imun berkembang selama tahap ini. Disfungsi imun dapat bermanifestasi sebagai infeksi bakteri, virus, protozoa, dan 
parasit seperti pyoderma bacterial, demodecosis, toxoplasmosis, kriptokokosis pada paru dan gingiostomatitis (Greene, 2012; Ettinger dkk, 2017). Penyakit akibat disfungsi imun terlihat lebih jelas daripada infeksi FIV, hal ini membuat FIV tidak menunjukkan gejala klinis sehingga sering terlambat terdiagnosa. Kasus ini memaparkan temuan tripanosomiasis dan FIV pada kucing yang terinfeksi secara alami, pendekatan diagnosa dan rekomendasi terapinya.

\section{Riwayat Kasus}

Seekor kucing domestik jantan, 3 tahun diperiksa di Rumah Sakit Hewan Prof. Soeparwi FKH-UGM dengan keluhan kedua mata terlihat berwarna putih, berawal dari mata kiri, berukuran kecil yang berkembang secara progresif selama 2 minggu, diikuti penurunan nafsu makan serta kondisi badan yang semakin kurus. Kucing berasal dari kucing jalanan, telah dipelihara selama 2 tahun, belum dilakukan vaksinasi, dipelihara secara bebas berkeliaran di sekitar rumah serta gemar memakan tikus maupun burung.

Hasil pemeriksaan klinis menunjukkan mukosa anemik, dehidrasi, oedema di daerah submandibular hingga bahu, BCS 4/9. Pemeriksaan mata menunjukkan adanya blepharospasm (ringan), hiperlakrimasi, konjungtivitis, aqueous flare serta kekeruhan pada anterior chamber yang mengarah pada akumulasi fibrin yang terlihat melayang di aqueous humor, bersifat progresif dan bilateral. Pemeriksaan laboratorium yang dilakukan berupa hematologi; kimia darah berupa SGPT, SGOT, glukosa, total kolesterol, BUN, kreatinin, rapid test FIV/FeLV dan rapid test toksoplasma serta pemeriksaan apus darah sebagai pendekatan diagnosa terhadap akumulasi fibrin dalam anterior chamber yang tidak normal. Pemberian rekomendasi rencana terapi pasien kucing berdasarkan pada diagnosa dan etiologinya.

\section{Hasil dan Pembahasan}

Mata yang terlihat putih akibat akumulasi fibrin dalam anterior chamber selama 2 minggu, bersifat progresif dan bilateral merupakan gejala klinis menciri yang disebabkan oleh beberapa agen infeksi. Fibrin di dalam anterior chamber merupakan produk radang yang umumnya meng- ikuti uveitis, diteguhkan dengan adanya aqueous flare akibat peningkatan kandungan protein pada aqueous humor (Townsend, 2008). Akumulasi fibrin dan aqueous flare umumnya juga mengandung leukosit yang disebut sebagai hypopon, namun diperlukan peneguhan analisa cairan aqueous humor dengan aqueouscenteces yang tidak diakukan pada kasus ini. Gejala klinis dan kondisi kucing dipaparkan pada Gambar 1.

Pemeriksaan dengan opthalmoskop menunjukan kondisi normal pada retina sehingga abnormalitas dipastikan terjadi pada bagian anterior dan mengarah pada uveitis anterior. Menurut Shukla dan Pinard (2012) anterior uveitis yang bersifat progresif dan bilateral mengindikasikan adanya infeksi sistemik dari virus (FIV, FeLV, FIP), protozoa (Toksoplasma gondiii) maupun sistemik mycosis.
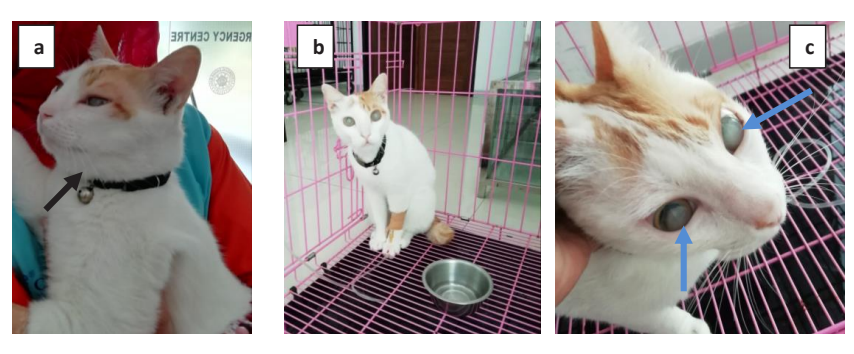

Gambar 1. Kondisi fisik pasien kucing. (a) terlihat adanya oedema pada daerah submandibular sinister hingga daerah brachialis sinister (tanda panah hitam); (b) terlihat bola mata berwarna putih bilateral dan progresif selama 2 minggu; (c) adanya akumulasi fibrin berupa masa putih yang melayang di dalam anterior chamber mata kanan dan kiri (tanda panah biru), permukaan kornea tampak halus dan tidak ada ulcer.

Infeksi Feline Immunodeficiency Virus (FIV) dan Feline Leukemia Virus (FeLV) dipertimbangkan menyebabkan anterior uveitis. Manifestasi okular umumnya terjadi pada kucing yang lebih tua (lebih dari 5 tahun), dan perubahan yang paling mencolok terlihat pada segmen anterior berupa uveitis kronis yang relatif ringan, aqueous flare, keratic precipitates, katarak kortikal, hiperemia iridal dan pembentukan nodul limfositplasmacytic iridal (Davidson dan English, 1998; Davidson, 2000; Colitz, 2005; Parry dan Maggio, 2007; Shukla dan Pinard, 2012; Greene, 2012).

Infeksi Feline Infectious Peritonitis (FIP) menimbulkan akumulasi fibrin dalam anterior chamber, namun juga dijumpai adanya radang pyogranulomatous di traktus uveal anterior dan 
posterior, serta lesi pada retina berupa retinal perivasculitis dan pyogranulomatous chorioretinitis. Mata merupakan organ target dari Toxoplasma gondii dan menjadi temuan utama toksoplasmosis pada berbagai spesies. Gejala klinis toksoplasmosis umumnya asimtomatik dan sangat jarang dilaporkan pada kucing dewasa, namun juga ditemukan pada kucing muda dan kucing dengan supresi imun karena terapi glukokortikoid ataupun supresi imun oleh virus FIV, FeLV dan FIP. Infeksi T. gondii menyebabkan uveitis anterior limfositik-plasmacytic dengan tandatanda klinis aqueous flare, perubahan iridal dan endapan keratik, namun pada kucing lesi ocular toksoplasmosis utamanya berupa inflamasi pada choroid dengan inflamasi sekunder pada retina (Davidson dan English, 1998; Davidson, 2000; Cucos dkk, 2005; Colitz, 2005; Parry dan Maggio, 2007; Greene, 2012; Shukla dan Pinard, 2012). Toksoplasmosis tidak berkaitan pada kasus ini dibuktikan dengan hasil negatif pemeriksaan rapid test antibody Toksoplasma. Hasil pemeriksaan klinis berupa, pemeriksaan mata dan hasil analisis laboratorium tidak mengarah pada kemungkinan mikosis sistemik, FIP, maupun toksoplasmosis. Hasil rapid test menunjukkan kucing positif antibodi FIV dan negatif antigen FeLV.
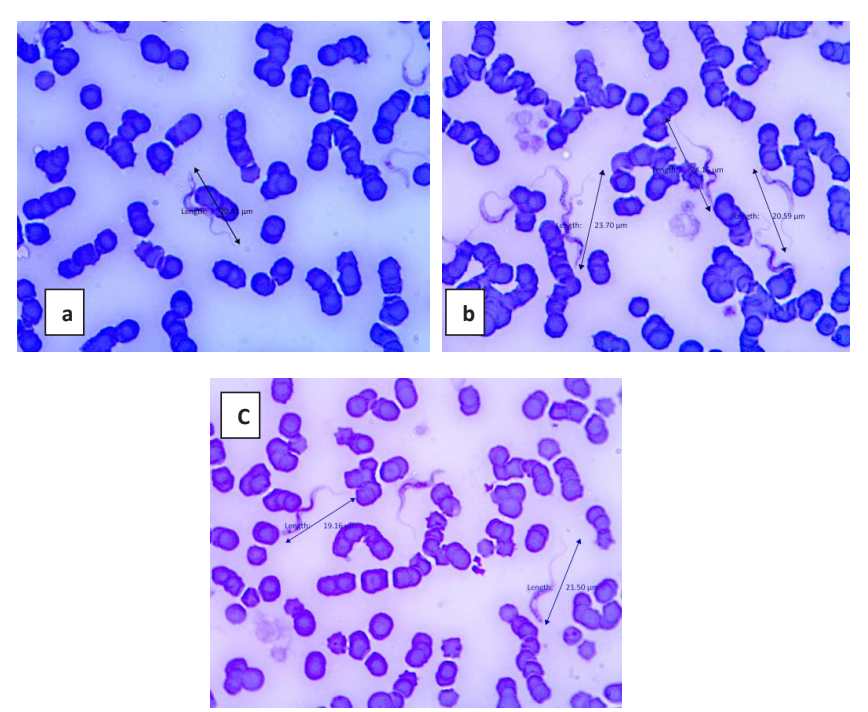

Gambar 2. (a)-(c) Trypanosoma sp yang ditemukan pada preparat apus darah. Trypanosoma $s p$ terlihat berbentuk slender "S-shape" dengan panjang rata-rata 21,28 $\mu \mathrm{m}$, memiliki free flagella di bagian anterior, adanya membran undulan, nucleus di dekat mid-body dan kinetoplas di ujung posterior. Bentuk ujung posterior umumnya terlihat tumpul, sebagian terlihat runcing. Sample darah EDTA, pengecatan gimza, perbesaran 100x objektif.
Kucing dipelihara secara bebas berkeliaran dan gemar memakan hewan liar, berpotensi tertular berbagai virus dari kucing lain melalui gigitan saat berkelahi serta rentan terjadi kontak dengan berbagai hospes intermediet seperti tikus dan berbagai ektoparasit sehingga perlu dipertimbangakan penyebab uveitis lainnya yang lebih luas. Kemungkinan penyebab uveitis anterior lain meskipun sangat jarang adalah Trypanosoma $s p$, yang juga dilaporkan menimbulkan kekeruhan mata pada kucing, anjing sapi dan kerbau. Hasil pemeriksaan apus darah memberikan gambaran bahwa kucing terinfeksi Trypanosoma $s p$. (Gambar 2.).

Menurut Bowman dkk (2002), Greene (2012) dan Nwoha (2013) tripanosomiasis dapat menginfeksi kucing baik secara alami maupun eksperimental, beberapa spesies yang sering menginfeksi antara lain Trypanosoma brucei, Trypanosoma evansi, Trypanosoma congolense, Trypanosoma cruzi, Trypanosoma rangeli dan Trypanosoma caninum. Tripanosoma yang ditemukan mengarah pada $T$. brucei maupun $T$. evansi, keduanya memiliki morfologi yang mirip dan sulit dibedakan. Ukuran kedua Tripanosoma hampir sama yaitu 7-23 $\mu \mathrm{m}$ pada $T$. brucei dan 15-34 $\mu \mathrm{m}$ pada T. evansi, predominant berbentuk slender "S-shape", memiliki 3-5 membaran undulan, panjang free flagellum $1 / 3-1^{1 / 3}$ pajang sel, nucleus berada didekat pertengahan badan, serta kinetoplas kecil yang berada di ujung posterior (Bowman dkk, 2002). Diduga kucing terinfeksi Trypanosoma $s p$ melalui vektor mekanik berupa lalat penggigit seperti Tabanus, Haematopota, Chrysops, Stomoxys, Musca ataupun melalui transmisi oral karena memakan rodensia yang terinfeksi Trypanosoma sp.

Hasil pemeriksaan darah (Tabel 1) menunjukkan adanya anemia normositik-hipokromik, trombositophenia, peningkatan nilai SGPT dan SGOT yang sangat tinggi, sedikit peningkatan creatinin, penurunan BUN, total cholesterol dan glukosa. Hasil pemeriksaan apus darah tidak menunjukkan gambaran regeneratif yang signifikan, meneguhkan pada kemungkinan anemia non-regeneratif. Anemia ini dapat disebabkan oleh inflamasi kronis, infeksi virus, gangguan sumsum tulang, hati maupun gagal ginjal, juga terjadi pada anemia pre-regeneratif. Menurut Misra dkk., 
Tabel 1. Hasil pemeriksaan hematologi dan kimia darah pasien kucing.

\begin{tabular}{|c|c|c|c|c|}
\hline \multicolumn{2}{|c|}{ Jenis Pemeriksaan } & Hasil Pemeriksaan & Nilai Referensi & Satuan \\
\hline \multicolumn{2}{|l|}{ Hemoglobin } & $8,5^{\mathrm{L}}$ & $9,5-15,0$ & $\mathrm{gr} / \mathrm{dL}$ \\
\hline \multicolumn{2}{|l|}{ Hematokrit } & $28,6^{\mathrm{L}}$ & $29,0-45,0$ & $\%$ \\
\hline \multicolumn{2}{|l|}{ Eritrosit } & $5,49^{\mathrm{L}}$ & $6,0-10,0$ & juta/ $/ \mu \mathrm{L}$ \\
\hline \multicolumn{2}{|l|}{$\mathrm{MCV}$} & 52,1 & $41,0-54,0$ & $\mathrm{fL}$ \\
\hline \multicolumn{2}{|l|}{$\mathrm{MCH}$} & 15,5 & $13,5-17,5$ & pg \\
\hline \multicolumn{2}{|l|}{$\mathrm{MCHC}$} & $29,7^{\mathrm{L}}$ & $31,0-36,0$ & $\%$ \\
\hline \multicolumn{2}{|l|}{ RDW } & 16,0 & - & $\%$ \\
\hline \multicolumn{2}{|l|}{ MPV } & 7,8 & - & $\mathrm{fL}$ \\
\hline \multicolumn{2}{|l|}{ PDW } & 17,2 & - & \\
\hline \multicolumn{2}{|l|}{ PCT } & 0,009 & - & $\%$ \\
\hline \multicolumn{2}{|l|}{ Trombosit } & $12^{\mathrm{L}}$ & $150-600$ & $\mathrm{ribu} / \mu \mathrm{L}$ \\
\hline \multicolumn{2}{|l|}{ Leukosit } & 9,9 & $5,5-19,5$ & $\mathrm{ribu} / \mu \mathrm{L}$ \\
\hline \multirow{2}{*}{ Neutrofil } & $\mathrm{R}$ & 39,4 & $35,0-75,0$ & $\%$ \\
\hline & A & 3,9 & $2,5-12,5$ & $\mathrm{ribu} / \mu \mathrm{L}$ \\
\hline \multirow{2}{*}{ Basofil } & $\mathrm{R}$ & 0,0 & $0,0-1,0$ & $\%$ \\
\hline & $\mathrm{A}$ & 0,0 & $0,0-0,1$ & $\mathrm{ribu} / \mu \mathrm{L}$ \\
\hline \multirow{2}{*}{ Eosinofil } & $\mathrm{R}$ & 5,0 & $2,0-12,0$ & $\%$ \\
\hline & A & 0,5 & $0,0-1,5$ & $\mathrm{ribu} / \mu \mathrm{L}$ \\
\hline \multirow{2}{*}{ Limfosit } & $\mathrm{R}$ & 50,2 & $20,0-55,0$ & $\%$ \\
\hline & $\mathrm{A}$ & 5,0 & $1,5-7,0$ & $\mathrm{ribu} / \mu \mathrm{L}$ \\
\hline \multirow{2}{*}{ Monosit } & $\mathrm{R}$ & $5,4^{\mathrm{H}}$ & $0,0-4,0$ & $\%$ \\
\hline & $\mathrm{A}$ & 0,5 & $0,0-0,85$ & $\mathrm{ribu} / \mu \mathrm{L}$ \\
\hline \multicolumn{2}{|l|}{ SGPT/ALT } & $\mathrm{HH}$ & $28,0-76,0$ & $\mathrm{IU} / \mathrm{L}$ \\
\hline \multicolumn{2}{|l|}{ SGOT/AST } & $\mathrm{HH}$ & $5,0-55,0$ & $\mathrm{IU} / \mathrm{L}$ \\
\hline \multicolumn{2}{|l|}{ Albumin } & 2,63 & $2,4-4,1$ & $\mathrm{gr} / \mathrm{dL}$ \\
\hline \multicolumn{2}{|l|}{ BUN } & $14,79^{\mathrm{L}}$ & $15,0-34,0$ & $\mathrm{mg} / \mathrm{dL}$ \\
\hline \multicolumn{2}{|l|}{ Creatinin } & $2,4^{\mathrm{H}}$ & $0,8-2,3$ & $\mathrm{mg} / \mathrm{dL}$ \\
\hline \multicolumn{2}{|l|}{ Glukosa } & 82,4 & $70,0-150,0$ & $\mathrm{mg} / \mathrm{dL}$ \\
\hline \multicolumn{2}{|c|}{ Cholesterol total } & $63,77^{\mathrm{L}}$ & $82,0-218,0$ & $\mathrm{mg} / \mathrm{dL}$ \\
\hline
\end{tabular}

Keterangan: $\mathrm{H}=$ high, $\mathrm{L}=$ low. Pemeriksaan hematologi menggunakan metode automatic hematologi analyzer, impedance Mindray BC-2800Vet. Pemeriksaan kimia darah menggunakan metode semi-automatic blood chemistry analyzer Caretium NB-201 reagen Stanbio. Referensi normal menurut Tilley dkk. dkk. (2016). Nilai SGPT dan SGOT sangat tinggi, tidak terbaca alat.

(2016), Nwoha (2013), Silva dkk., (2009ª) anemia juga ditemukan pada kucing yang diinokulasi Tripanosoma secara eksperimental.

Nilai SGPT dan SGOT yang sangat tinggi dan hipokolesterolaemia mengarah pada kerusakan hepatosit penyakit hati primer seperti hepatitis aktif-kronis, cholagiohepatitis, hepatotoxic. Peningkatan tersebut tidak mengarah pada kerusakan hepatosit sekunder dari penyakit ekstrahepatik seperti pancreatitis, penyakit gastrointestinal, periodontal, endokrin maupun penyakit jantung, berdasarkan temuan klinis dan laboratorium lainnya. Penyebab hipokolesterolaemia lain yaitu portosystemic shunt maupun malnutrisi berat. Diperlukan pemeriksaan lanjutan berupa alkalin phosphatase, gamma GT, dan bilirubin untuk menggambarkan gangguan hati yang lebih spesifik. Penurunan BUN dapat disebabkan oleh hepaticfailure maupun malnutrisi. Peningkatan creatinin mengarah pada azotemia yang perlu dibedakan antara pre-renal, renal, maupun post-renal azotemia dengan pemeriksaan urinalisis dan ultrasonography (USG) (Villiers dkk, 2016).

Tripanosomiasis dan infeksi FIV menyebabkan beberapa manifestasi klinis yang sama, yang juga ditemukan pada kasus ini baik dari hasil pemeriksaan klinis maupun laboratorium, antara lain uveitis, penurunan massa otot, anemia, dan periportal hepatitis (Silva dkk. 2009a; Greene, 2012; Nwoha, 2013; Misra dkk. 2016). Tidak menutup kemungkinan adanya asosiasi antara 
infeksi FIV dengan tripanosomiasis, dimana FIV diduga termasuk dalam tahap kronis asimtomatis yang menyebabkan disfungsi imun sehingga kucing rentan terhadap infeksi lain baik bakteri, virus maupun parasit. Kedua penyakit tersebut juga berpotensi meningkatkan kerusakan fungsi organ dan beresiko menimbulkan kematian yang lebih besar daripada infeksi tunggal.

Tripanosomiasis pada kasus ini lebih akut daripada infeksi FIV. Periode prepaten pada kucing yang diiinokulasi tripanosoma secara eksperimental adalah 5-15 hari pasca infeksi Trypanosoma evansi dan 5 hari pasca infeksi Trypanosoma brucei serta 44 hari pada kucing yang diberi makan mencit yang terinfeksi Trypanosoma brucei. Kematian kucing terjadi pada 40-56 hari pasca infeksi $T$. evansi secara eksperimental dan 22-26 hari pasca infeksi T. brucei secara eksperimental (Bowman, 2002). Diagnosa FIV yang menggunakan rapid test merupakan deteksi antibody, dimana antibodi terbentuk setelah 60 hari terpapar virus dan pada infeksi persisten FIV (Greene, 2012). Hal ini menjadi pertimbangan dalam membuat rencana terapi.

Terapi tripanosomiasis yang disarankan adalah injeksi dimenazine aceturat $3.5 \mathrm{mg} \cdot \mathrm{kg}^{-1}$ q24 jam selama 5 hari berturut-turut. Efektivitas dimenazine aceturat mencapai $85.7 \%$ pada kucing yang terinfeksi Trypanosoma sp secara eksperimental (Silva dkk, 2009 ${ }^{\text {b }}$ Greene, 2012; Nwoha, 2013). Pemberian dimenazine aceturat pada 3-7 hari pasca infeksi T. evansi secara eksperimental menghasilkan kesembuhan yang permanen. Keterlambatan pemberian dimenazine aceturat, lebih dari 14 hari pasca infeksi T. evansi secara eksperimental akan menimbulkan kekambuhan akibat $T$. evansi yang telah menginvansi jaringan otak sedangkan dimenazine aceturat tidak dapat melewati barrier otak. Kekambuhan tripanosomiasis juga dapat disebabkan oleh resistensi Trypanosoma terhadap (Silva dkk, 2009 ). Reinfeksi memungkinkan terjadi apabila kucing masih dalam lingkaran siklus hidup Tripanosoma $s p$. Terapi supportif juga dipertimbangkan untuk memperbaiki kondisi yang diakibatkan oleh tripanosomiasis maupun infeksi FIP seperti infus intravena yang mengandung glucose, antibiotik spektrum luas yang terdistribusi sampai jaringan mata namun aman untuk fungsi hati, hepatoprotektan, preparat imunosupportif dan eritrophoetin.

Diperlukan investigasi lebih lanjut mengenai spesies Trypanosoma yang ditemukan pada kasus, patogenesitas terhadap kucing dan rute infeksi untuk mencegah reinfeksi, penularan terhadap kucing lain maupun adanya potensi zoonosis.

\section{Kesimpulan}

Akumulasi fibrin di dalam anterior chamber yang bersifat progresif-bilateral disertai dengan aqueous flare dan normal retina merupakan gambaran anterior uveitis sebagai gejala klinis yang menciri dari tripanosomiasis dan infeksi Feline Immunodeficiency Virus pada kucing.

\section{Ucapan Terima kasih}

Penulis berterima kasih kepada drh. Bagus Brahmanto Aji G.,M.Sc dari PDHB Dji'o Pet Care \& Vet dan drh. Sugiyono, M.Sc dari Departemen Patologi FKH UGM atas diskusi dalam penulisan naskah.

\section{Daftar Pustaka}

Bowman, Dwaight D., Hendrix, Charles M., Lindsay, David S., Barr, and Stephen C. (2002). Feline Clinical Parasitology. Wiley-Blackwell, Iowa.

Cucos, C., Ionascu, I., Mocanu, J., and Militaru, M. (2015). Neurogical and Ocular Form of Toxoplasmosis in Cats. Scientific Works. Series C. Veterinary Medicine, 61(1):95-97.

Colitz, C. M. H. (2005). Feline Uveitis: Diagnosis and Treatment. Clinical Techniques in Small Animal Practice, 20(2):117-120.

Davidson, M., and English, R. (1998). Feline Ocular Toxoplasmosis. Veterinary Ophthalmology. 1:71-80.

Davidson, M. G. (2000). Toxoplasmosis. Veterinary Clinics of North America: Small Animal Practice. 30(5): 1051-1062.

Ettinger, Stephen J., Feldman, Edward C., Cote, Etienne. (2017). Textbook of veterinary Internal Medicine: Disease of the Dog and the Cat $8^{\text {th }}$ Edition. Elsevier Saunders, Missouri. 
Greene Craig E. (2012). Infectious Diseases of the Dog and Cat $^{4^{\text {th }}}$ Edition. Elsevier Saunders, Missouri.

Tilley, Patric, L., Francis, W.K. and Smith, Jr. (2016). Blackwell's five-minute veterinary consult: canine and feline, $6^{\text {th }}$ Edition. Ames, Iowa:Blackwell.

Misra, K.K., Roy, S., and Choudhury, A. (2016). Biology of Trypanosoma (Trypanozoon) evansi in experimental heterologous mammalian hosts. Journal of parasitic diseases : official organ of the Indian Society for Parasitology, 40(3): 1047-1061.

Nurcahyo, W. (2017). Penyakit Surra pada Hewan dan Ternak. Samudra Biru, Yogyakarta. ISBN 978-602-5610-17-2 (In Press).

Nwoha, I. (2013). A Review on Trypanosomosis in Dogs and Cats. African Journal of Biotechnology. 12: 6432-6442.

Parry, N., \& Maggio, F. (2007). Uveitis in cats. Companion Animal, 12(3): 70-78.

Shukla, A., and Pinard, C. (2012). Feline Uveitis. Compendium (Yardley, PA). 34:E1-E9.
Silva, A.S., Pierezan, F., Wolkmer, P., Costa, M.M., Oliveiro, C.B., Tonin, A., Santurio, J., Lopes, S., and Monteiro, S. (2009a). Pathological Findings Associated with Experimental Infection by Trypanosoma evansi in Cats. Journal of comparative pathology. 142:170-176.

Silva, A.S., Zanette, R.A., Wolkmer, P., Costa, M.M., Garcia, H., Lopes, S., Santurio, J., Teixeira, M., and Monteiro, S. $\left(2009^{\mathrm{b}}\right)$. Diminazene aceturate in the control of Trypanosoma evansi infection in cats. Veterinary parasitology. 165:47-50.

Townsend, W. M. (2008). Canine and Feline Uveitis. Veterinary Clinics of North America: Small Animal Practice, 38(2): 323-346.

Villiers, E., Ristic, J., and Blackwood, D.L. (2016). BSAVA Manual of Canine and Feline Clinical Pathology, 3rd Edition. John Wiley \& Sons. 